\title{
The Minimum Tick and Stock Market Liquidity: The Case of Dubai and the Abu Dhabi Capital Markets
}

\author{
Ghassan Omet ${ }^{1}$, Hadeel Yaseen ${ }^{2} \&$ Morad Abdel-Halim ${ }^{3}$ \\ ${ }^{1}$ Finance, Faculty of Business, Department of Finance, the University of Jordan, Amman, Jordan \\ ${ }^{2}$ Banking and Finance Department, Applied Science Private University, Amman, Jordan \\ ${ }^{3}$ General Budget Department, Ministry of Finance, Amman, Jordan \\ Correspondence: Ghassan Omet, Finance, Faculty of Business, Department of Finance, the University of Jordan, \\ Amman, Jordan. E-mail: gomet@ju.edu.jo
}

Received: March 6, 2015

Accepted: May 4, $2015 \quad$ Online Published: June 20, 2015

doi:10.5539/ijbm.v10n7p67

URL: http://dx.doi.org/10.5539/ijbm.v10n7p67

\begin{abstract}
In the framework of the financial and stock market literature, several economic concepts have been developed and considered including the concept of operational efficiency of stock markets. Basically, an efficient and liquid market permits investors to obtain the executed orders as fast and at reasonable prices as possible. This study provides answers for two major questions. The first question is what are the costs of liquidity which prevail in both Dubai and Abu Dhabi capital markets? Secondly, has the reduction in March 2000 in the minimum tick size in Dubai capital market led to a development in the operational efficiency of the capital market? Using data for an overall of 22 institutions which are listed on both markets and also based on a daily basis through the period from the first of October 2009 till first of August 2010, the practical investigations point out that liquidity cost in both markets is quite high. In addition, the outcomes obviously show that the decrease in the minimum tick size of the listed corporations on Dubai Capital Market have led to the preferred goal which is decreasing the cost of liquidity.
\end{abstract}

Keywords: financial markets, spread, minimum tick size, Abu Dhabi, Dubai, liquidity cost

\section{Introduction}

Following the traditional and classical arguments put forward by Robinson (1952) and Schumpeter (1934), various hypothetical and practical research papers have examined the task and role of financial improvement in economic development and what determines the spread of financial institutions and financial securities instruments. In addition the role of capital markets in economic growth is tested. Additionally, financial development has been examined in terms of its effect on the growth of firms, poverty, along with income level allocation.

Banks and financial institutions such as insurance firms and others are expected to provide financial services along with capital markets which encourage the growth of the economy at macro and micro levels (Levine, 1991). They reduce transaction costs and information costs, and promote savings, improve the efficiency in capital allocation, spread risks, and moreover provide more liquidity.

As the concern in this study about the role of stock markets in economic growth, it is remarkable to note and precisely in the previous decade, stock exchange markets have been established in a few of the slightest likely spaces, as of Azerbaijan and Zambia. This could be to some extent due to the significant body of literature which has recognized a positive correlation among the level of financial development and economic growth (Minier, 2009). In the literature, there are two arguments that are related to the stock markets development to the investment levels in countries and their economic growth.

Argument one (level effect) is attributed to Levine (1991) and Bencivenga (1995). The argument includes that with no liquid secondary markets, investors would find it is hard to finance long-term project. In other words, the existence of highly liquid secondary markets solve the dilemma of funding long term investments, and this due to that investors are allowed to liquidate their portfolios without difficulty, reasonably, and at any point of time they decide. 
The second argument about the efficiency effects, which is attributed to Greenwood and Jovanovic (1990), and also Obstfeld (1994). Once more, the presence of liquid secondary markets allows investors to expand and diversify their portfolios, and a result, they are able to invest in more risky financial instruments that offer high returns. The diversification of instruments is a benefit and is expected to get better and more efficiency in the allocation and distribution of capital flows.

Notwithstanding the point that financial stock markets can be important in economic terms, the issue of operational efficiency is interesting for several reasons. For instance, published articles indicate a negative correlation between the cost of liquidity and stocks yields. This could imply that firms stocks with a lesser liquidity have, on average, lesser returns, and therefore, this could imply a higher cost of capital (Acharya \& Pedersen, 2005). Moreover, a smaller amount of liquid stocks are expected to pay off for public offering, higher banking fees and consequently have high cost of capital, Butler (2005), and Mantecon and Poon (2009). It is also declared that "ultimately, market design and regulation shape the degree of investor participation, the competitiveness of financial markets, economic growth, and social welfare" (Degryse, 2009).

For a combination of reasons, together with the implications of firms' cost of capital, the issuance of stock market liquidity has resulted in a various set of empirical papers. For example, Ahn (2007), and Ascioglu (2010), Bourghelle and Declerck (2001), Aitken and Comerton-Forde (2005) investigated the effect of a decline in the minimum tick size on operational liquidity costs. In addition, the impact of stock liquidity on the value of the firm, the structure of capital, and the impact of financial deregulation, stock split, and cross listing on liquidity cost have been examined by Ascioglu (2010), Heibatollah and Zhou (2008), and Hansen and Sung Suk (2013). A number of researches have also investigated whether or not the introduction of specialists results in lesser liquidity cost (Frino, 2008).

Following the early research articles, published by Demsetz (1968), Tinic (1972), and Tinic and West (1974), the literature that examined the relationships between liquidity cost and stocks' characters has become so huge even to evaluate and review. On average, however, this effort regresses a measurement of the cost of liquidity on a vector of characters that include, for instance, risk or volatility of stocks, trading volume liquidity, the size of the firm, and the price of stocks, foreign ownership, and others. Some of these papers include Benston and Hagerman (1974), Glosten and Harris (1988), Frino et al. (2008), Chai et al. (2010), Chekili and Abaoub (2013), Ding et al. (2013), and Madyan et al. (2013).

The fact that securities markets can have positive economic implications at the macro and micro levels, most of the Arab economies have established stock markets. For example, the Dubai financial market (DFM) and Abu Dhabi stock exchange (ADSE) were established in 2000. Since then, these markets have increased their listed firms from 30 and 13 to 66 and 55 respectively. Naturally, this enlargement in listed firm's number has resulted in a reciprocal rise in market capitalization. The Abu Dhabi's capitalization has increased from $\$ 30.3$ billion to more than $\$ 109$ billion by the end of 2013. Similarly, the capitalization of the Dubai Financial market has also risen from about $\$ 14$ billion to $\$ 70.7$ billion in 2013 . We have to notice that by end of year 2013 , the capitalization of both markets constitute on $9.7 \%$, and $6.3 \%$ of the capitalization of all other Arab countries financial market respectively.

In addition, and close to the Dubai Financial Market, it is worth noting that on March $11^{\text {th }}$ in 2010 , the market has altered its minimum tick size. The latest regulation enables investors to apply 3 decimal tick sizes on their financial instruments with a market value beneath one Dirham. Hence, this gives the traders the opportunity to deal with financial securities with a division of fills.

The main purpose of this study is to give an answer to the next three issues. First, in this study we are going to quantify the cost of liquidity that prevails in the DFM as well as ADSE. Second, we are going to examine if the changes that happened on March 2000, altering the smallest amount tick size in Dubai stock market, led to a development in its operational efficiency. The third issue is to compare the liquidity costs of the two markets with other emerging and developed financial stock markets.

\section{The Methodology, Data, Observations and Results}

The market-making mechanisms which exist in DFM and ADSE are order-driven. Most dealers and investors should deal with brokers and the market orders are given priority for exercising in according to their time and prices. Similarly, by submitting consecutive buying and selling orders, investors and dealers offer liquidity for new participants whom claim immediacy by placing opposite market orders.

The essential set of data were gathered that is used in this study is collected from the daily trading reports of each market. The reports publish a number of measurements that includes traded stock's numbers, trading volume and 
transactions numbers, the closing price, and in addition the highest and lowest transaction prices are recorded.

In each trading day, both markets, at the close, publish the highest and lowest buying prices and selling prices. These prices are for counter orders, which did not get executed on ending of every trading day. The variation among these prices can be used as a measurement of the cost of liquidity. One can argue, that this differentiation between the closing prices highest and lowest (bid \& ask prices) at the end of every trading day is an excellent gauge of liquidity cost. This is a good proof for the idea that the arrival times of the close bid and ask prices are casual and random. These mean that over a time period, the daily closing finest bid and ask price reflects a better measurement of the cost of liquidity.

In addition, during the period from 1-10-09 to 1-10-10 and based on daily basis closing bid and ask prices, we calculate the next day by day measure of the spreads for an overall 22 corporations which has listed in ADSE and also for 22 corporations listed in DFM.

$\left.\operatorname{SPREAD}_{\mathrm{i}, \mathrm{t}}=\left[\left(\mathrm{ASK}_{\mathrm{i}, \mathrm{t}}-\mathrm{BID}_{\mathrm{i}, \mathrm{t}}\right) / \mathrm{Q}_{\mathrm{i}}\right)\right]^{*} 100$ where $\mathrm{Q}_{\mathrm{i}}$ refer to the average between bid prices and ask prices of share i.

Furthermore and following the literature, and also based on the availability of data, we have used trading frequencies, stock prices, volatility of prices, and firm size in order to give an explanation of the cross-sectional variation in the spread (bid-ask).

We have used the next regression model which can be written as follow:

$$
\text { Spread }_{I, t}=\alpha_{0}+\alpha_{1} \ln \left(\text { vol }_{I, t}\right)+\alpha_{2} \ln \left(\text { price }_{I, t}\right)+\alpha_{3} \text { Risk }_{I, t}+\alpha_{4} \ln \left(\text { Size }_{I, t}\right)+\alpha_{5} \text { Own } n_{I, t}+\varepsilon_{I, t}
$$

where Spread is the spread (bid-ask), $\operatorname{vol}_{\mathrm{I}, \mathrm{t}}$ is trading volume, (price $\mathrm{I}_{\mathrm{I}, \mathrm{t}}$ ) refers to 1 plus the natural logarithm of stock's price, (Risk $\mathrm{I}_{\mathrm{I}, \mathrm{t}}$ is the differentiation between the lowest and highest price divided by the closing price, $\left(\mathrm{Size}_{\mathrm{I}, \mathrm{t}}\right)$ is defined as the market price of the firm equity, and $\left(\mathrm{Own}_{\mathrm{I}, \mathrm{t}}\right)$ refers to the percentage of the stocks that are owned by individuals who hold $5 \%$ or more of the stocks, and ln is natural logarithm.

The selected shares are the most traded in the markets. This means that these stocks are selected depending on the fact that these stocks have every day transactions and the daily ending bid-ask prices for at least $75 \%$ of the days for the period of the 10 months.

In so far as the changes in the minimum tick rules in Dubai Financial Market is concerned, the specific time period from first of October 2009 to first of August 2010, enable us to determine on a daily basis the bid-ask spreads for the whole 5 months prior to and later than the changes in the minimum tick rules. Which means, in the above mentioned model 1 , we added a dummy variable used to determine the changes in the minimum tick rule. Also, we have examined model (1) depending on the $1^{\text {st }}$ sub period the 5 months moreover the $2^{\text {nd }}$ five months sub-period had examined one by one. In reality, if the coefficients of the stock's prices in the $2^{\text {nd }}$ period is less than stock's prices in the $1^{\text {st }}$ sub period, this illustrates that the changes in the minimum tick rule has led to a decrease in the cost of liquidity.

Tables 1, 2 and 3 show the fundamental information concerning the spread measure, and the independent variables for both markets. Three observations can be noticed.

First of all, the mean values of spread measures are quite high (about $1.5 \%$ in both markets). This rate is higher than those values in developed markets. The NYSE for example marks $0.0181 \%$ while in NASDAQ about $0.0373 \%$ (Jiang, 2011). Correspondingly, the $1.5 \%$ cost of liquidity is higher than the $0.331 \%$ and $0.213 \%$ that are present in the European exchanges and Canada respectively (Gagnon \& Gimet, 2013), while in China $0.217 \%$ (Ding et al., 2013). Obviously, these observations indicate that investors in the ADSE and DFM cannot be assured of getting their orders executed whenever they want, and when they get them executed, the incur high cost.

Table 1. Spread estimate: some basic information

\begin{tabular}{lll}
\hline & DFM & ADSE \\
\hline MEAN & 1.655 & 1.544 \\
MEDIAN & 1.007 & 1.238 \\
MAXIMUM & 11.007 & 9.003 \\
MINIMUM & 0.10 & .01 \\
S. D & 1.452 & 1.100 \\
Number of Observation & 4600 & 1656 \\
\hline
\end{tabular}


$\mathrm{SPREAD}=\left[(\right.$ Ask $\left.\left.-\mathrm{Bid}) / \mathrm{Q}_{\mathrm{i}}\right)\right]^{*} 100$ where $\mathrm{Q}$ refer to the midpoint between the BID \&ASK prices of stock.

Table 2. Spread estimate: sub-periods

\begin{tabular}{lll}
\hline & $1^{\text {st }}$ Sub-Period & $2^{\text {nd }}$ Sub-Period \\
\hline ADSE & 1.479 & 1.606 \\
DFM & 1.426 & 1.655 \\
\hline
\end{tabular}

Second, some of the listed corporations have extremely high liquidity cost. This can be noticed from the highest values of the spread measure. This value is equal to $9.3 \%$ in ADSE and $11.2 \% \mathrm{t}$ in DFM (Table 1).

Table 3. Mean values of independent variables

\begin{tabular}{ccc}
\hline Variable & Abu Dhabi & Dubai \\
\hline SPREAD & 0.015 & 0.015 \\
VOL & 13.868 & 14.366 \\
PRICE & 1.649 & 1.102 \\
RISK & 2.729 & 3.378 \\
SIZE & 27.281 & 21.102 \\
OWN & 0.457 & 0.529 \\
\hline
\end{tabular}

Sources: by author's estimations.

Third, in so far as both markets are concerned, the mean value of the spread measure in the 2 nd sub period as is higher than in the first sub-period (Table 2).

Fourth, both markets are different in a number of independent variables (Table 3). The figures disclose that the risk measurement in Dubai Financial Market is greater than the figure in Abu Dhabi Market. As a final point, the mean size of corporations listed on the ADSE is much larger than the DFM's corporations.

Tables 4 to 6 report the empirical results.

Table 4. The estimation results for both sub-periods

\begin{tabular}{ccc}
\hline & ADSE & DFM \\
\hline Variables & $-0.508^{*}$ & $-0.590^{*}$ \\
Vol & $-0.457^{*}$ & $-0.162^{*}$ \\
Price & $0.289^{*}$ & $0.311^{*}$ \\
Risk & $0.133^{*}$ & $0.200^{*}$ \\
Size & $-0.201^{*}$ & $-0.018^{*}$ \\
Own & $\ldots \ldots$ & $-0.094^{*}$ \\
Dummy & 0.290 & 0.501 \\
Adj. R & 1.693 & 1.636 \\
D.W & $185.220^{*}$ & $540.920^{*}$ \\
F test & &
\end{tabular}

*Significant at the 99 percent level.

Sources: by author's estimations.

Again, and based on these results, we can notice the following observations. First, the coefficient of the variable Price has a significant and negative relationship in both markets (Table 4). These results indicate that shares with a high price have, on average, a lower cost of liquidity. These results are anticipated for the reason that the minimum tick is generalized to all listed securities irrespective of their prevailing market prices. Second, as far as the Dubai market is concerned, the results show that the coefficient of the dummy variable is significant and negative. This indicates that the dropping in the minimum tick rule has led its objective which is the reducing liquidity cost.

Third, when we compare the Abu Dhabi Financial Market with the Dubai Market in terms of the independent variable (price), an interesting result is observed. The coefficients in ADSE are equal to -0.375 and -0.345 in the 
two sub-periods (Table 5). On the other hand, in the case of the Dubai market, these coefficients are equal to -0.349 in the first sub-period and to -0.091 in the second sub-period (Table 6). Undoubtedly, this decline in the value of this coefficient from -0.349 to -0.091 indicates that the preface of the new minimum tick rule has led to a reduction in the effects of stock prices on the cost of liquidity.

Table 5. Estimation results: ADSE market

\begin{tabular}{lll}
\cline { 2 - 2 } Variable & $\begin{array}{l}\text { Coefficient } \\
\text { First Sub-Period }\end{array}$ & $\begin{array}{l}\text { Coefficient } \\
\text { Second Sub-Period }\end{array}$ \\
\cline { 2 - 3 } Vol & $-0.407^{*}$ & $-0.428^{*}$ \\
PRICE & $-0.375^{*}$ & $-0.345^{*}$ \\
RISK & $0.168^{*}$ & $0.242^{*}$ \\
SIZE & $0.146^{*}$ & $0.136^{*}$ \\
OWN & $-0.171^{*}$ & $-0.159^{*}$ \\
Adjusted R & 0.349 & 0.302 \\
D-W Statistic & 1.875 & 1.765 \\
F-Statistic & $111.444^{*}$ & $90.790^{*}$ \\
\hline
\end{tabular}

*Significant at the 99 percent level.

Finally, the rest of the independent variables have, on average, the predictable signs. The effect of volume of trading on the spread has a negative sign indicating that in general illiquid stock tends to have a wider spread (bid-ask). In addition, the coefficient of risk is constantly significant and positive. In fact, when volatility is small, one should expect that narrower bid-ask spreads. The coefficient of firm's size is also significant and positive. This result is unexpected as one would have anticipated that bigger corporations tend to be more-known and consequently their bid-ask spread tend to be narrower than minor and less-known corporations. Nevertheless, the fact that the markets have not been established for a long time, this argument is most likely not applicable.

Table 6. Regression results: Dubai financial market

\begin{tabular}{lll}
\hline Variable & Coefficient & Coefficient \\
& First Sub-Period & Second Sub-Period \\
\hline VOL & $-0.501^{*}$ & $-0.843^{*}$ \\
PRICE & $-0.349^{*}$ & $-0.091^{*}$ \\
RISK & $0.130^{*}$ & $0.331^{*}$ \\
SIZE & $0.169^{*}$ & $0.156^{*}$ \\
OWN & $-0.089^{*}$ & $-0.054^{*}$ \\
Adjusted $\mathrm{R}^{2}$ & 0.320 & 0.453 \\
D-W Statistic & 1.543 & 1.721 \\
F-Statistic & $280.767 *$ & $461.137^{*}$ \\
\hline
\end{tabular}

Note. *Significant at the 99 percent level.

\section{A Summary and Conclusions}

The theoretical argument about the positive impact of financial development on economic growth is, on average, supported by the empirical literature. This is why, stock markets, as a component of financial systems, have attracted a fair share of research papers. This effort examines various aspects of the performance of stock markets and these include, for example, the determinants of the cost of liquidity, impact of reducing the minimum tick size on liquidity cost, impact of stock split on liquidity cost, inpact of cross-listing on liquidity cost, and the impact of liquidity cost on capital structure, and firm value.

This paper tried to provide answers to four questions: first, what is the cost of liquidity that prevails in the Abu Dhabi and Dubai markets? Second have the changes in March 2000 in the minimum tick size in Dubai market imply an improvement in the operational efficiency of the market? Third, how does liquidity cost in these two Arab markets compare with other emerging and developed financial stock markets? Fourth, are generally known determinants of liquidity cost applicable to these Arab stock markets?

$\mathrm{Bu}$ using the financial data of 22 firms listed on both Abu Dhabi Financial market and Dubai Financial market 
for the time period between $1 / 10 / 2009-1 / 8 / 2010$, the results indicate that the liquidity costs in these capital markets are somewhat high compared to other developed markets. This result affirms some strict assessment, and based on the international literature, the introduction of market-makers (specialists) might be the remedy. In addition, while well-known determinants of liquidity cost is applicable to both markets, the findings without a doubt indicate that the decline in the minimum tick in the Dubai capital market has led to a decrease in liquidity cost.

\section{References}

Acharya, V., \& Pedersen, L. (2005). Asset Pricing with Liquidity Risk. Journal of Financial Economics, 77, 375-410. http://dx.doi.org/10.1016/j.jfineco.2004.06.007

Ahn, H., Cai, J., Chan, K., \& Hamao, Y. (2007). Tick Size Change and Liquidity Provision on the Tokyo Stock Exchange. Journal of the Japanese International Economies, 21, 173-194. http://dx.doi.org/10.1016/j.jjie.2005.10.008

Aitken, M., \& Comerton-Forde, C. (2005). Do Reductions in Tick Sizes Influence Liquidity? Accounting and Finance, 45, 171-184. http://dx.doi.org/10.1111/j.1467-629x.2004.00128.x

Ascioglu, A., Comterton-Forde, C., \& McInish, T. (2010). An Examination of Minimum Tick Sizes on the Tokyo Stock Exchange. Japan and the World Economy, 22, 40-84. http://dx.doi.org/10.1016/j.japwor.2009.06.006

Bencivenga, V., Smith, B., \& Starr, R. (1995). Transaction Costs, Technological Choice, and Endogenous Growth. Journal of Economic Theory, 67, 53-177. http://dx.doi.org/10.1006/jeth.1995.1069

Benston, G., \& Hagerman, R. (1974). Determinants of Bid-Ask Spreads in the Over-the-Counter Market. Journal of Financial Economics, 1, 353-364. http://dx.doi.org/10.1016/0304-405X(74)90014-2

Berkman, H., \& Nguyen, N. (2010). Domestic Liquidity and Cross-Listing in the United States. Journal of Banking and Finance, 34, 1139-1151. http://dx.doi.org/10.1016/j.jbankfin.2009.11.011

Bourghelle, D., \& Declerck, F. (2001). A New Price Grid for the Bourse: Euro Trading. Execution Costs and Liquidity Provision on the Paris Bourse. Working Paper. Toulouse University.

Brennan, M., \& Subrahmanyam, A. (1996). Market Microstructure and Asset Pricing: On the Compensation for Illiquidity in Stock Returns. Journal of Financial Economics, 41, 441-464. http://dx.doi.org/10.1016/0304-405X(95)00870-K

Butler, A., Grullon, G., \& Weston, J. (2005). Stock Market Liquidity and the Cost of Issuing Equity. Journal of Financial and Quantitative Analysis, 40, 331-348. http://dx.doi.org/10.1017/S0022109000002337

Chai, D., Faff, R., \& Gharghori, P. (2010). New Evidence on the Relation Between Stock Liquidity and Measures of Trading Activity. International Review of Financial Analysis, 19, 181-192. http://dx.doi.org/10.1016/j.irfa.2010.02.005

Chekili, S., \& Abaoub, N. (2013). Estimation of the Bid-Ask Spread: Applications on the Tunis Stock exchange. Global Business and Economics Research Journal, 2, 24-33.

Degryse, H. (2009). Competition between Financial Markets in Europe: What Can be Expected from MiFID? Financial Markets and Portfolio Management, 23, 93-103. http://dx.doi.org/10.1007/s11408-008-0095-5

Demsetz, H. (1968). The Cost of Transacting. The Quarterly Journal of Economics, 82, 33-53. http://dx.doi.org/10.2307/1882244

Ding, M., Nilsson, B., \& Suardi, S. (2013). Foreign Institutional Investors and Stock Market Liquidity in China: State Ownership, Trading Activity and Information Asymmetry. Working Paper No. 14, The Knut Wicksell Centre for Financial Studies, Lund University. http://dx.doi.org/10.2139/ssrn.2241832

Frino, A., Gerace, D., \& Lepone, A. (2008). Liquidity in Auction and Specialist Market Structures: Evidence from the Italian Bourse. Journal of Banking and Finance, 32, 2581-2588. http://dx.doi.org/10.1016/j.jbankfin.2008.05.010

Gagnon, M., \& Gimet, C. (2013). The Impacts of Standard Monetary and Budgetary Policies on Liquidity and Financial Markets: International Evidence from the Credit Freeze Crisis. Journal of Banking and Finance, 37, 4599-4614. http://dx.doi.org/10.1016/j.jbankfin.2013.04.003

Glosten, L., \& Harris, L. (1988). Estimating the Components of the Bid-Ask Spread. Journal of Financial Economics, 19, 123-142. http://dx.doi.org/10.1016/0304-405X(88)90034-7

Greenwood, J., \& Jovanovic, B. (1990). Financial Development, Growth, and the Distribution of Income. 
Journal of Political Economy, 98, 1076-1107. http://dx.doi.org/10.1086/261720

Hansen, S., \& SungSuk, K. (2013). Influence of Stock Liquidity to Firm Value in Indonesian Stock Market. The 2013 IBEA, International Conference on Business, Economics, and Accounting, Bangkok, Thailand.

Heibatollah, S., \& Zhou, H. (2008). The Economic Consequences of Increased Disclosure: Evidence from Cross-Listings of Chinese Firms. Journal of International Financial Management and Accounting, 19, 1-27. http://dx.doi.org/10.1111/j.1467-646X.2008.01014.x

Jain, P. (2003). Institutional Design and Liquidity of Stock Exchanges around the World. Working Paper. Indiana University. http://dx.doi.org/10.2139/ssrn.869253

Levine, R. (1991). Stock Markets, Growth, and Tax Policy. Journal of Finance, 46, 1445-1465. http://dx.doi.org/10.1111/j.1540-6261.1991.tb04625.x

Madyan, M., Salim, U., \& Anshori, M. (2013). Liquidity Determinants of Sharia and Non Sharia Stocks. IOSR Journal of Business and Management, 9, 28-38. http://dx.doi.org/10.9790/487X-0922838

Mantecon, T., \& Poon, P. (2009). An Analysis of the Liquidity Benefits Provided by Seconday Markets. Journal of Banking and Finance, 33, 335-346. http://dx.doi.org/10.1016/j.jbankfin.2008.08.008

Minier, J. (2009). Opening a Stock Exchange. Journal of Development Economics, 90, 135-143. http://dx.doi.org/10.1016/j.jdeveco.2008.10.002

Obstfeld, M. (1994). Risk-Taking, Global Diversification, and Growth. American Economic Review, 84, 1310-1329.

Robinson, J. (1952). The Generalization of the General Theory. London, UK: MacMillan

Schumpeter, J. (1934). The Theory of Economic Development, Translated by Redvers Opie. Cambridge, USA: Harvard University Press.

Tinic, S. (1972). The Economics of Liquidity Services. The Quarterly Journal of Economics, 86, 79-93. http://dx.doi.org/10.2307/1880494

Tinic, S., \& West, R. (1974). Marketability of Common Stocks in Canada and the USA: A Comparison of Agent Versus Dealer Dominated Markets. The Journal of Finance, 3, 729-746. http://dx.doi.org/10.1111/j.1540-6261.1974.tb01480.x

\section{Copyrights}

Copyright for this article is retained by the author(s), with first publication rights granted to the journal.

This is an open-access article distributed under the terms and conditions of the Creative Commons Attribution license (http://creativecommons.org/licenses/by/3.0/). 